ДО ПРОБЛЕМИ ВИХОВАННЯ МАЙСТЕРНОСТІ АРТИСТІВ ХОРУ

\title{
TO THE PROBLEM OF EDUCATION OF SKILLS OF CHOIR ARTISTS
}

Основний дослідницький ракурс полягає у висвітленні проблемних питань, які потребують уваги при вихованні майстерності артистів хору. Внаслідок розвитку музичного матеріалу, який є основою виконавського репертуару різних колективів, потрібно враховувати необхідність оновлення методичних підходів. Студенти диригентсько-хорових відділень мають опановувати низку дисциплін, які сприяють розвитку їхньої майстерності як майбутніх диригентів-хормейстерів та артистів хору.

На основі аналізу сучасних хорових партитур робиться висновок про те, що комплексний підхід вбачається як найбільш доцільний. Він передбачає залучення теоретичних знань, що надають відомості про історико-культурний розвиток хорового виконавства, типи хорів, особливості голосів. Увага має звертатися на формування вокальної майстерності, проте необхідне не лише володіння голосовим апаратом, а й глибоке знання теоретичних дисциплін. Потрібне опанування навичок роботи над хоровим текстом, його аналізом і розробленням репертуару для різних колективів. Для хормейстерів та артистів хору необхідною $є$ аналітична діяльність, яка буде пов'язана із компаративістикою різних виконавських інтерпретацій.

На основі сучасних хорових творів, зокрема опусів В. Зубицького, продемонстровано, що кожен хорист має бути фрахівцем високого рівня, який здатний бути артистом-солістом. Хорова тканина віднині ні в чому не поступається оркестровій музиці ані за складністю, ані за новаторськими прийомами. У творах B. Зубицького виявляються усі можливості людських голосів: використовуються віртуозні швидкі пасажі, глісандо, звуконаслідування звучання народних інструментів, крайні регістри вокальних голосів. Значна тривалість творів, зростання вокальної складності, формування акордових вертикалей нетерцієвої структури створюють низку аспектів, на які потрібно звертати увагу артистам хору. Сучасна підготовка студентів на диригентсько-хорових відділеннях повинна включати зразки хорових творів композиторів, які лише нещодавно виникли.
Ключові слова: диригент-хормейстер, хор, артист, виховання, аналіз, майстерHicmь, хорист.

The main research perspective is to highlight the problematic issues that need attention in the education of the skills of choir artists. Due to the development of musical material, which is the basis of the performance repertoire of various groups, it is necessary to take into account the need to update methodological approaches. Students of conducting and choir departments must master a number of disciplines that contribute to the development of their skills as future conductors-choirmasters and choir artists.

Based on the analysis of modern choral scores, it is concluded that an integrated approach is seen as the most appropriate. It involves the involvement of theoretical knowledge that provides information about the historical and cultural development of choral performance, types of choirs and features of voices. Attention should be paid to the formation of vocal skills, but it is necessary not only to have a voice, but also a deep knowledge of theoretical disciplines. It is necessary to master the skills of working on a choral text, its analysis and development of repertoire for different groups. Choirmasters and choir artists need analytical work that will be related to the comparative studies of different performing interpretations. On the basis of modern choral works, in particular V. Zubytsky's opuses, it is demonstrated that every chorister should be a high-level specialist who is capable of being a soloist. From now on, the choral fabric is not inferior to orchestral music, neither in complexity nor in innovative techniques. In the works of $V$. Zubytsky all the possibilities of human voices are manifested. Virtuoso fast passages, glissando, sound imitation of the sound of folk instruments, extreme registers of vocal voices are used. The considerable duration of the works, the growth of vocal complexity, the formation of chord verticals of the non-tertiary structure create a number of aspects that need to be paid attention to by the choir artists. Modern training of students in conducting and choral departments should include samples of choral works by composers, which have only recently emerged.

Key words: conductor-choirmaster, choir, artist, education, analysis, skill, chorister. Київського національного університету культури і мистецтв

Постановка проблеми в загальному вигляді. Підготовка артистів хору відбувається у багатьох закладах освіти мистецького спрямування. Хоча на перший погляд може здаватися, що будь-яка людина, здобувши музичну освіту, здатна бути артистом хору, проте це не зовсім відповідає дійсності. Адже фахова профільна професійно орієнтована підготовка, що здійснюється на диригентсько-хорових відділеннях, дає змогу готувати набагато вищого рівня виконавців. Розвиток музичної практики зумовлює зростання вимог до артистів хору. Тому доречно буде визначити ті проблемні моменти, що постають перед виконавцямихористами у процесі виконавської діяльності, та визначити характеристики, на які необхідно звертати увагу в процесі їх фахової підготовки. Пропонується окреслити виконавські аспекти, виховання яких потребує додаткової уваги, на прикладі творів, що входять до репертуару хорових колективів.

Аналіз останніх досліджень і публікацій. Різні аспекти діяльності диригента-хормейстера та проблеми виховання артистів хору аналізува- 
лися у роботах вітчизняних мистецтвознавців. Питання підготовки майбутнього диригента-хормейстера до профресійної оцінної діяльності досліджувалося Л. Костенко та Л. Шумською. Діяльність диригента-хормейстера як соціокультурний феномен представлена у публікації Ю. ПучкоКолесник. Методичні рекомендації із хорознавства О. Сбітнєвої структуровано представляють основні завдання, які постають при вихованні хорових диригентів. Методологічні аспекти виховання артиста хору виділено у статті А. Левченко. Особливості хорового концерту В. Зубицького досліджувала Я. Кириленко.

Виділення не вирішених раніше частин загальної проблеми. Питання виховання майстерності артистів хору, яке унаочнюється крізь призму творів сучасних композиторів, ще не здобувало висвітлення у науково-педагогічній літературі.

Мета статті - виявити питання, які потребують уваги при вихованні майстерності артистів хору на прикладі творів сучасних композиторів.

Виклад основного матеріалу. Виховання майстерності артистів хору здійснюється на диригентсько-хорових фракультетах, де можливі такі спеціалізації, як «академічний хор» і «народний хор». Базові вимоги, які висуваються до артистів хору, $є$ спільними незалежно від спеціалізації. Серед того кола завдань, які мають засвоїти студенти, варто зазначити майстерність артистів хору. Кожен із тих, хто навчається на цій спеціалізації, може стати не лише учасником хорового колективу як вокаліст, а й бути диригентом-хормейстером. Формування фрахівця такого рівня передбачає охоплення низки вмінь, які зумовлюють теоретичні знання та практичні навички.

«Отже, сучасний диригент-хормейстер насамперед повинен володіти широкими знаннями, багатою ерудицією, при цьому у найрізноманітніших галузях: від сольфеджіо, історії музики і вокалу до педагогіки і психології. Широкі й ґрунтовні знання, ерудиція керівника хору, в тому числі профресійна, добре відчувається артистами хору, адже, щоб колектив повірив диригентові, правоті його творчих задумів і намірів, він повинен переконати співаків» [5, с. 134].

Зазначимо, що профресійність студента диригентсько-хорового відділення оцінюється через досягнення низки компетенцій, які виявляються у таких показниках: «мануальна техніка диригента», «діагностика хорового звучання» або «управлінська сугестія» [5, с. 123]. Важливим $є$ опанування й теоретичних дисциплін (наприклад, хорознавство). Вказана дисципліна включає вивчення історичних аспектів, пов'язаних із розвитком хорового мистецтва, виробленням навичок роботи над хоровим текстом, його аналізом та розробленням репертуару для різних колективів.
Важливими є навички здійснення розвідок, пов'язаних із виявленням особливостей творів, які виконуються колективами. Студент має досліджувати твір, здійснюючи компаративний аналіз щодо інших творів, які написані на той самий текст, сюжет або присвячені тій самій темі. Необхідно виявляти власну позицію щодо музичного тексту. Цей процес включає такі обов'язкові компоненти: «Порівняння різних виконавських інтерпретацій. Визначення значення твору в наші дні $з$ позицій сучасного музично-хорового мистецтва» [6, с. 73].

Диригент $€$ виконавцем, проте його діяльність $€$ більш складною, ніж у вокалістів та інструменталістів, адже його «інструментом» $є$ цілий колектив виконавців, які мають співпрацювати, бути готовими відтворювати ту версію, яка обрана хормейстером. Це володіння «інструментом» постає таким, що складається 3 великої кількості задач. Це не лише самоорганізація, а й спроможність організувати кожного хориста, допомогти у разі виникнення проблем і скерувати у потрібне русло.

Якщо ж визначити особливості виховання майстерності хористів, то слід зауважити, що чимала складність полягає в опануванні нового музичного матеріалу, який вбирає в себе низку традиційних рис, що можуть бути присутніми на рівні фрорми та містити новаторські елементи музичної мови. Наприклад, при розучуванні творів українського сучасного композитора Володимира Зубицького, який створив низку масштабних інструментальнохорових жанрів, а саме кантату, кантату-симсронію, реквієм, симфонію-реквієм, треба зауважувати, що він використовує всі можливості хорового складу та оркестру. Його хорове мистецтво нерідко пов'язане 3 духовною тематикою, а виконання творів потребує осмислення стратегій передачі сенсу. «Духовні твори сучасних композиторів від початку не призначені для здійснення прикладної фрункції у богослужінні, тому передбачають лише опосередковане втілення сакрального смислу та ідейно-змістовної основи літургії виключно засобами музичної виразності. Такий підхід відкриває для композитора великі можливості для вияву особистісного творчого начала у сорері сакрального» [5, с. 133].

Наступним чинником, на який необхідно звертати увагу, виконуючи твори Зубицького, є розуміння природи його творчості, в яких відводиться чільне місце принципам неофольклоризму та неокласицизму. «Композиторському стилеві притаманні щедрий мелос, що спирається на українські фрольклорні джерела у поєднанні із найсучаснішими засобами музичного мислення й оригінальною інструментовкою, вільне оперування характерними прийомами музичних стилів різних епох, тяжіння до театралізації» [1, с. 172].

Для індивідуального стилю композитора фрольклор є тематичною основою творів, сконструйованих крізь призму сучасного мислення, для якого 
сполучення різних технік композиції виступає вже звичним методом. Тому уявна простота деяких епізодів, що мають тональну основу, не визначає загальної стилістики усього твору, а нерідко співвідноситься зі складними у плані хорової вертикалі та горизонталі поєднаннями.

Також неабиякої уваги хормейстера та виконавців потребує дисонантність, що утворюється внаслідок використання акордів нетерцієвої структури. Для їх виконання артисти хору повинні мати розвинену гармонічну мову, великий слуховий багаж і вміти відтворювати будь-які звукові комплекси. «Особливої уваги вимагає засвоєння гармонічної мови сучасних хорових партитур. Наш музичний слух вихований здебільшого на гармонічних співзвуччях терцового складу. Проте в сучасній музиці широкого розповсюдження набули квартові, квінтові й секундові сполучення. У пошуках нових засобів виразності композитори йдуть шляхом індивідуалізації акордів. Так «народжуються» нові співзвуччя зі змішаною структурою. Тому в колективі необхідною $є$ робота з розвитку гармонічного слуху на основі не лише класичної, а й сучасної гармонії» [5, с. 134].

Кожен хорист має бути фрахівцем високого рівня, який здатний бути артистом-солістом. Саме такі вимоги потрібні, щоб виконувати сучасну хорову партитуру. Хорова тканина в інтерпретації Зубицького ні в чому не поступається оркестровій музиціані за складністю, ані за новаторськими прийомами. В його творах виявляються усі можливості людських голосів: віртуозні швидкі пасажі, глісандо, звуконаслідування звучання народних інструментів (дримби), використання крайніх регістрів вокальних голосів - низьких чоловічих і високих жіночих дозволяють повністю розкрити авторський задум. «Хорова поліфонія має при цьому колористичний характер, для чого використовуються різні теситурні прийоми, а також спеціальні способи хорового інтонування (спів закритим ротом, скандування тексту та окремих голосних звуків, рецитація без фріксованої звуковисотності)» [2, с. 153].

Наприклад, у народній симфонії єднання «Україна» В. Зубицького використовується великий виконавський склад - мішаний хор, симфонічний оркестр та оркестр народних інструментів. Причому масштабність підкреслюється не лише обсягом виконавців, а й тривалістю, адже навіть одна IV частина «Щедрик» у різних інтерпретаціях звучить близько 47-48 хвилин. Тому такий твір потребує значної витривалості. Причому потрібно при виконанні підкреслювати зв'язок із різними фольклорними жанрами.

Попри назву «Щедрик», у творі є відсилання не лише до щедрівки, а й до інших фольклорних жанрів. Зокрема, на початку частини нерідкими є фррагменти танцювального характеру. Загостреність ритму, елементи гуцульського ладу створюють алюзію на жанр коломийки. Ці ознаки, притаманні концерту «Гори мої», окреслює Я. Кириленко: «Типовий для гуцульського фрольклору жанр коломийки з її характерною метрикою та ритмом, що існують як у «квадратному» варіанті, так і у вигляді поліметрії та поліритмії, характерних для імпровізацій (здебільшого інструментальних) на «коломийкові» мелодії» [2, с. 149]. Усі ці ритмічні особливості також потребують уваги виконавців і нерідко можуть становити складність при виконанні.

Хор трактується у симфонії надзвичайно різноманітно. Він не лише використовується в епізодах, де поєднується вокал і слово, але й відіграє роль «інструментальної» фрарби, коли додає певних тембральних фрормант, вокалізуючи без слів. Нерідко В. Зубицький застосовує принцип поліметрії, що створює багатошаровість звучання оркестру. Крім цього, для твору притаманне використання принципу полістилістики. Це створює картину змінюваного часу від прадавніх синкретичних дійств до постіндустріального суспільства, яке поєднується елементами щедрівки. Усі ці аспекти мають враховуватися при виконанні.

Як можна побачити з побіжного аналізу підходу, який наявний у хорових опусах В. Зубицького, відбувається поступове трансорормування ролі хору. «Розвиток музичного простору вимагає постійного перегляду аспектів виховання артистів хору. Виконавська практика диктує нові вимоги до співаків. Актуальності не втрачають необхідність вправного володіння голосовим апаратом та інтонаційної вірності» [4, с. 565]. Внаслідок цього необхідно використовувати новітній музичний матеріал для підвищення результативності підготовки студентів спеціальності «Хорове диригування».

Низка складнощів, які зумовлені зростанням складності творів, спричиняють потребу в оновленні методичних розробок. Для формування високопрофесійних хормейстерів і артистів хору потрібно акцентувати увагу на комплексному підході, який має виявлятися у ґрунтовному аналізі твору. Це сприятиме глибинному розумінню причини появи тих чи інших елементів у музичній тканині та тому, яким чином вони мають інтерпретуватися виконавцями.

Висновки. Загалом можна зауважити, що у творах сучасних композиторів розширюються межі застосування хору, який використовується як у звичному вокальному амплуа, так і набуває інструментальних рис. Значна тривалість творів, зростання вокальної складності, фрормування акордових вертикалей нетерцієвої структури створюють низку аспектів, на які потрібно звертати увагу артистам хору. Надзвичайно велика амплітуда динамічних відтінків потребує нюансування рівня звучності хору. Зростання ролі нових технік композиції потребує уваги до тренування гармонічного слуху виконавців, розширення їхнього 
музичного світогляду. Тому сучасна підготовка студентів на диригентсько-хорових відділеннях повинна включати зразки хорових творів композиторів, які лише нещодавно виникли. Це готуватиме їх до професійної діяльності. Саме на творах сучасних авторів має здійснюватися підготовка з інших теоретичних дисциплін.

Перспективи подальших досліджень. Доцільним буде виділення тих новітніх зразків композиторського хорового письма, які доречно використовувати для розвитку гармонічного слуху, навичок аналізу музичної партитури.

\section{БІБЛІОГРАФІЧНИЙ СПИСОК:}

1. Зубицький Володимир Данилович. Українська музична енциклопедія. Т. 2: [E - К]; гол. редкол. Г. Скрипник. Київ : Видавництво Інституту мистецтвознавства, фольклористики та етнології НАН України, 2008. С. 172.
2. Кириленко Я.А. Хоровой концерт В. Зубицкого «Гори мої»: неофольклорная модель претворения жанра. Вісник Харківської державної академії дизайну і мистецтв, 2012. № 2. С. 148-153.

3. Костенко Л., Шумська Л. Підготовка майбутнього диригента-хормейстера до професійної оцінної діяльності. Витоки педагогічної майстерності, 2019. Вип. 23. С. 122-127. https://doi.org/10.33989/2 075-146x.2019.23.183220.

4. Левченко А.В. Методологічні аспекти виховання артиста хору. Молодий вчений, 2018. № 3(55). C. $563-566$.

5. Пучко-Колесник Ю. Діяльність диригентахормейстера як соціокультурний феномен. Вісник HАККіM, 2013. № 3. С. 132-136.

6. Сбітнєва О.Ф. Хорознавство : метод. рек. для студ. спец. «Середня освіта (музичне мистецтво)» заочної фрорми навчання. Старобільськ : Вид-во ДЗ «ЛНУ імені Тараса Шевченка», 2017. 86 с. 